\title{
Development of Randomly Amplified Polymorphic DNA Based SCAR Marker for Identification of Ipomoea mauritiana Jacq (Convolvulaceae)
}

\author{
Kambiranda Devaiah, ${ }^{1,2}$ Subramani Paranthaman Balasubramani, ${ }^{1}$ \\ and Padma Venkatasubramanian ${ }^{1}$ \\ ${ }^{1}$ Centre for Pharmacognosy, Pharmaceutics and Pharmacology, Foundation for Revitalization of Local Health Traditions (FRLHT), \\ via Yelhanka, Bangalore 560106, India \\ ${ }^{2}$ Center for Viticulture and Small Fruit Research, Florida A \& M University, 6505 Mahan Drive, Tallahassee, FL 32317, USA
}

Correspondence should be addressed to Padma Venkatasubramanian, padma.venkat@frlht.org

Received 28 October 2009; Accepted 1 March 2010

Copyright (C) 2011 Kambiranda Devaiah et al. This is an open access article distributed under the Creative Commons Attribution License, which permits unrestricted use, distribution, and reproduction in any medium, provided the original work is properly cited.

Vidari is an Ayurvedic herbal drug used as aphrodisiac, galactagogue and is also used in the preparation of Chyavanaprash. Tubers of Ipomoea mauritiana Jacq. (Convolvulaceae), Pueraria tuberosa (Roxb. ex Willd.) DC (Fabaceae), Adenia hondala (Gaertn.) de Wilde (Passifloraceae) and pith of Cycas circinalis L. (Cycadaceae) are all traded in the name of Vidari, creating issues of botanical authenticity of the Ayurvedic raw drug. DNA-based markers have been developed to distinguish I. mauritiana from the other Vidari candidates. A putative 600-bp polymorphic sequence, specific to I. mauritiana was identified using randomly amplified polymorphic DNA (RAPD) technique. Furthermore, sequence characterized amplified region (SCAR) primers (IM1F and IM1R) were designed from the unique RAPD amplicon. The SCAR primers produced a specific 323-bp amplicon in authentic I. mauritiana and not in the allied species.

\section{Introduction}

Vidari is one of the popular plant drugs of Ayurveda and is a component of many popular and highly traded Ayurvedic formulations like Chyavanaprash, an ancient Indian dietary supplement. The Ayurvedic Pharmacopoeia of India correlates "Vidari" to tubers of Pueraria tuberosa (Roxb. ex Willd.) DC (Fabaceae) and Ipomoea mauritiana Jacq. (Convolvulaceae) as "Kshiravidari" [1]. However, a recent report by Venkatasubramanian et al. [2] indicates that as per Ayurvedic descriptions they both have similar properties and can be substituted by each other. Several herbal medicine manufacturing units also use the giant potato or $I$. mauritiana (Syn. I. paniculata or I. digitata) as Vidari instead of $P$. tuberosa. Vidari is useful as aphrodisiac, cardiotonic, demulcent, diuretic, refrigerant and galactogogue [3]. It is also used in emaciation, enteric fever and spermatorrhea [4]. The annual trade volume of Vidari is $\sim 500-1000$ Metric Tonnes [5].
Ipomoea mauritiana is a branched perennial climber with large tuberous tap roots and glabrous stems and branches; leaves palmately 5-7 lobed; flowers purple, in pedunculate corymbose axillary panicles; fruits ovoid, fourcelled and four-valved capsules, surrounded by enlarged fleshy sepals, seed clothed with many long tawny cottony hairs. The root tubers exude milky, sticky, latex and exhibits annual rings when cut. This species is widely naturalized in tropical parts of the world [6]. Taraxerol, taraxerol acetate, umbelliferone, $\beta$-sitosterol, scopoletin and 7-O- $\beta$ D-glycopyranosyl scopoletin (Scopolin) have been isolated from the methanol extract of the tubers [7]. The roots are used to increase appetite, as a galactagogue, in rejuvenative medicine, as a stimulant, carminative and tonic [8]. Alcohol extract of tubers is stimulant as well as depressant, and has convalescent effect on central nervous system $[9,10]$.

Apart from tubers of $P$. tuberosa and I. mauritiana, tubers of Adenia hondala (Gaertn.) de Wilde (Passifloraceae) and the pith of Cycas circinalis L. (Cycadaceae) are also traded 
in the name of Vidari [5]. The Ayurvedic Pharmacopoeia of India stipulates macro-microscopic evaluation and chemical profiling of the botanical materials for quality control and standardization [1]. Use of macro, micro and chemical techniques for authentication has its advantages and disadvantages [11], while molecular markers, once standardized is fool-proof, easy and objective [12].

Molecular genetic tools like barcoding, random amplified polymorphic DNA (RAPD) and sequence characterized amplified region (SCAR) markers are reliable methods for quality control of herbal materials. Fingerprints obtained by RAPD can be employed for identification of raw drug at the molecular level [13], however since it is difficult to reproduce these fingerprints they are preferentially converted to SCAR markers. Molecular marker technology proves to be valuable tool not only for genotyping of medicinal plants but also for detecting adulterations and substitutions in herbal medicines [14-17].

In our study, we have developed RAPD profile of $I$. mauritiana, P. tuberosa, A. hondala and C. circinalis. Subsequently, a unique DNA sequence identified from the RAPD profile of I. mauritiana was used to develop a speciesspecific SCAR marker. This marker is useful to distinguish I. mauritiana from its allied species traded as Vidari.

\section{Methods}

2.1. Plant Material. Field and market samples were collected from different geographical regions across India. Plant samples were authenticated by qualified field botanist and an Ayurvedic practitioner at Foundation for Revitalization of Local Health Traditions (FRLHT). The voucher samples were deposited in the Herbarium and Raw Drug Repository (FRLHT, Bangalore, India). The details of the plant samples used in this study are presented in Table 1.

2.2. Reagents and Chemicals. CTAB (20\% (w/v)), $1 \mathrm{M}$ Tris$\mathrm{HCl}(\mathrm{pH} 8), 5 \mathrm{M}$ EDTA (pH 8), $5 \mathrm{M} \mathrm{NaCl}, 3 \mathrm{M}$ sodium acetate, ethanol, chloroform-isoamyl alcohol $(24: 1(\mathrm{v} / \mathrm{v}))$, polyvinylpyrrolidone (PVP) (40000 $\mathrm{mol} \cdot \mathrm{wt})$ (Sigma), and $\beta$-mercaptoethanol. All the chemicals used in the experiments were of analytical grade. Enzymes (Taq Polymerase and RNase A), Taq buffer, $\mathrm{MgCl}_{2}$ and dNTPs for polymerase chain reaction (PCR) amplification were purchased from Bangalore Genei (Bangalore, India).

2.3. DNA Extraction. Dried raw plant materials were chopped into small pieces and powdered using liquid nitrogen in mortar and pestle. Samples were later homogenized using CTAB extraction buffer and processed as described in the protocol of Milligan [18]. The extracted DNA was treated with $5 \mu \mathrm{L}$ of RNase A $(10 \mathrm{mg} / \mathrm{mL})$ to remove any contaminating RNA. Purity and yield of DNA were checked using UV Spectrophotometer (UV Pharmaspec 1700, Shimadzu, Tokyo, Japan) by calculating the $\mathrm{A}_{260} / \mathrm{A}_{280}$ [19].

2.4. RAPD Reaction. The PCR was performed by adding $25 \mathrm{ng}$ of plant DNA, $2 \mathrm{mM}$ dNTP mix, $30 \mathrm{pM}$ of primer,
TABLE 1: Details of the plant samples used in the study.

\begin{tabular}{lll}
\hline $\begin{array}{l}\text { Name of the } \\
\text { plant species }\end{array}$ & Accession number & Place of collection \\
\hline $\begin{array}{l}\text { Pueraria } \\
\text { tuberosa }\end{array}$ & $\mathrm{L} / 07 / 10 / 028$ & Belgaum, Karnataka \\
& $\mathrm{L} / 07 / 02 / 032$ & $\begin{array}{l}\text { Pune, Maharastra } \\
\mathrm{L} / 04 / 07 / 009\end{array}$ \\
\hline Ipomoea & $\mathrm{L} / 08 / 08 / 014$ & Not Available \\
mauritiana & $\mathrm{L} / 08 / 08 / 018$ & Kollukayal, Kerala \\
& $\mathrm{L} / 08 / 08 / 019$ & Kollukayal, Kerala \\
\hline Adenia & $\mathrm{L} / 07 / 08 / 009$ & Thiruinelli, Kerala \\
hondala & $\mathrm{L} / 07 / 08 / 025$ & Kozhikode, Kerala \\
& $\mathrm{L} / 09 / 02 / 006$ & Kambamda, Kerala \\
\hline \multirow{2}{*}{$\begin{array}{l}\text { Cycas } \\
\text { circinalis }\end{array}$} & $\mathrm{L} / 02 / 01 / 006$ & Not Available \\
& $\mathrm{L} / 07 / 09 / 006$ & Bangalore, Karnataka ${ }^{\mathrm{a}}$ \\
\hline
\end{tabular}

${ }^{a}$ Market sample authenticated by botanist.

$2.5 \mu \mathrm{L}$ of $10 \times$ PCR buffer, $2.5 \mathrm{mM} \mathrm{MgCl}_{2}, 2.0 \mathrm{U}$ of Taq DNA Polymerase (Bangalore Genei, India) and made up to $25 \mu \mathrm{L}$ with distilled water. The reaction was performed in a thermal cycler (Eppendorf Master Cycler Gradient, Hamburg, Germany). Reaction conditions were as follows: $94^{\circ} \mathrm{C}-3 \mathrm{~min}$, 40 cycles of $94^{\circ} \mathrm{C}-30 \mathrm{~s}, 36^{\circ} \mathrm{C}-30 \mathrm{~s}, 72^{\circ} \mathrm{C}-1 \mathrm{~min}$ and a final extension of $72^{\circ} \mathrm{C}$ for $10 \mathrm{~min}$. PCR products were resolved in a horizontal gel electrophoresis system (Classic CSSU1214, Thermo Electron, MA, USA) along with standard 100-bp ladder and $\lambda$ DNA EcoR I/HindIII double digest (Bangalore Genei, India) on a $1.2 \%$ agarose, $0.5 \times$ TBE gel. The DNA was stained with ethidium bromide $(0.5 \mu \mathrm{g} / \mathrm{mL})$. The gel was visualized under UV radiation in a Camag Reprostar (022.9610, CAMAG, Muttenz, Switzerland) and digitally photographed (Canon, Tokyo, Japan). RAPD was performed with 40 random decamer primers (OPA 1-20 and OPF 1-20) obtained from Operon Technologies (Alameda, CA, USA). Electrophoretic profiles were analyzed for polymorphism based on the presence and absence of DNA bands on agarose gel. Confirmation of results was done using at least three different samples of each species. Experiment was repeated at least three times to confirm species-specific fingerprinting pattern and reproducibility.

2.5. Cloning and Sequencing of the Polymorphic Band. The putative marker amplified by the random primer OPA 18 was excised from $1.2 \%$ agarose gel with sterile gel slicer and purified using the QIAquick Gel extraction kit (Qiagen, Maryland, USA). The purified fragment was reamplified using the primer OPA 18 with the same PCR conditions, except for the final extension, which was increased to $20 \mathrm{~min}$ to facilitate cloning into TA cloning vector. About $2 \mu \mathrm{L}$ of the purified DNA was ligated into a pDRIVE vector and transformed into Qiagen EZ competent cells following the manufacturer's instructions (Qiagen, Maryland, USA). Ten distinct white colonies were picked from the LB/ampicillin/X-gal/IPTG plate and recombinant plasmid was isolated from each overnight grown colony. The presence 
TABLE 2: Details of the I. mauritiana specific SCAR marker designed from the 600-bp polymorphic sequence.

\begin{tabular}{lcccc}
\hline $\begin{array}{l}\text { Name of random } \\
\text { decamer primer used }\end{array}$ & $\begin{array}{c}\text { Sequence of random } \\
\text { decamer primer } \\
\left(5^{\prime}-3^{\prime}\right)\end{array}$ & $\begin{array}{c}\text { Name of the SCAR } \\
\text { primer }\end{array}$ & $\begin{array}{c}\text { Sequence of the SCAR primer } \\
\left(5^{\prime}-3^{\prime}\right)\end{array}$ & $\begin{array}{c}\text { Annealing } \\
\text { temperature }\left({ }^{\circ} \mathrm{C}\right)\end{array}$ \\
\hline OPA18 & AGGTGACCGT & IM1F & ACTTGGGATAGGCTGACACG & 60 \\
& IM1R & GGTAAACCGGGATGGTTCTT & 60 \\
\hline
\end{tabular}

of insert was confirmed by reamplifying the DNA using the OPA 18 under similar RAPD conditions. The recombinant plasmid was purified using the Quicklyse Mini prep kit (Qiagen, Maryland, USA). DNA insert was sequenced on an ABI 310 Automated Sequencer (Applied Biosystems, CA, USA) using vector specific universal promoter primers SP6 (5'-CATACGATTTAGGTGACACTATAG- $\left.3^{\prime}\right)$ and T7 (5'TAATACGACTCACTATAGGG- $3^{\prime}$ ) by Bioserve Biotechnologies (Hyderabad, India).

2.6. SCAR Primer Designing and Validation. Based on the sequence of unique RAPD amplicon a pair of SCAR oligonucleotide primers (IM $1 F$ and IM1R), which could amplify $\sim 323 \mathrm{bp}$ of the genomic DNA of I. mauritiana was designed (Table 2). The oligos were custom-synthesized by Bioserve Biotechnologies (Hyderabad, India). The SCAR primer pair was used for PCR amplifications of genomic DNA from all the Vidari species. The reaction mixture contained $25 \mathrm{ng}$ of plant DNA, $0.6 \mathrm{mM}$ dNTP mix, $30 \mathrm{pM}$ of primer, $2.5 \mu \mathrm{L}$ of $10 \times$ PCR buffer, $1.5 \mathrm{mM} \mathrm{MgCl}_{2}, 1.0 \mathrm{U}$ of Taq DNA Polymerase (Bangalore Genei, India) and made up to $25 \mu \mathrm{L}$ with distilled water. PCR conditions for amplification using SCAR primers were optimized as: $95^{\circ} \mathrm{C}$ for $3 \mathrm{~min} ; 35$ cycles of $95^{\circ} \mathrm{C}$ for $35 \mathrm{~s}, 60^{\circ} \mathrm{C}$ for $30 \mathrm{~s}, 72^{\circ} \mathrm{C}$ for $45 \mathrm{~s}$ and a final extension at $72^{\circ} \mathrm{C}$ for $3 \mathrm{~min}$. The SCAR primers were validated using three accessions each of $I$. mauritiana, $P$. tuberosa, A. hondala and C. circinalis while repeating each experiment three times.

\section{Results}

3.1. DNA Extraction and RAPD. High molecular weight genomic DNA was isolated from the fresh as well as dried plant samples. The DNA extraction procedure yielded $400-600 \mathrm{ng}$ of DNA per $100 \mathrm{mg}$ of tissue. An absorbance $\left(\mathrm{A}_{260} / \mathrm{A}_{280}\right)$ ratio of 1.6-1.8 indicated insignificant levels of contaminating proteins and polysaccharides. All the 40 random decamer primers used for screening, produced distinct, reproducible fingerprint of I. mauritiana, $P$. tuberosa, C. circinalis and A. hondala. OPA 18 consistently amplified an intense 600-bp band that was unique to I. mauritiana samples and invariant with all the three accessions of this species tested (Figure 1). This 600-bp amplicon was not observed in the other three species under study.

3.2. Cloning and Sequencing of Polymorphic Band. Ipomoea mauritiana specific 600-bp polymorphic band was cloned

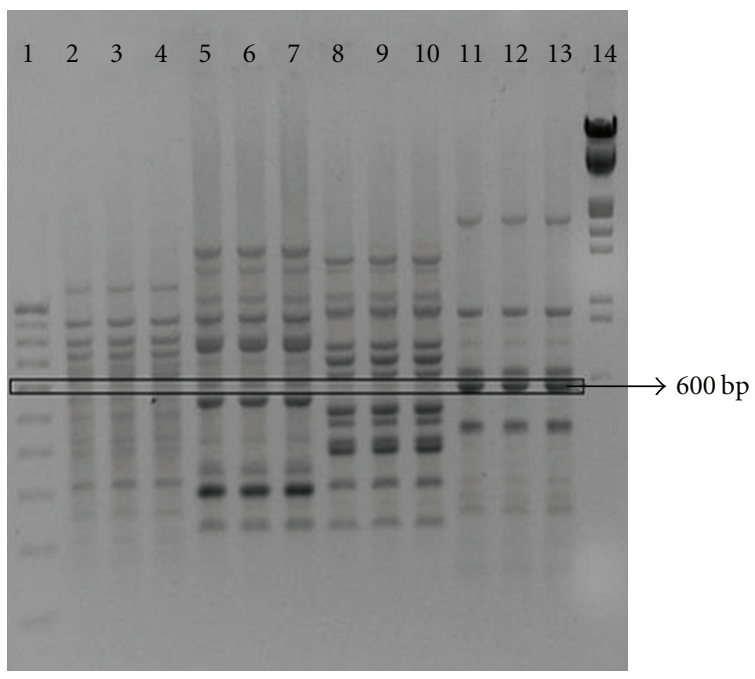

FIGURE 1: RAPD pattern of Vidari candidates. Lane: $1-$ Standard DNA marker (100-bp DNA ladder); 2-4-A. hondala; 5-7-C. circinalis; 8-10-P. tuberose; 11-13-I. mauritiana; 14-Standard DNA marker ( $\lambda$ DNA EcoR I/HindIII double digest).

into pDRIVE cloning vector and transformed into Qiagen EZ competent cells. The selected white colonies contained the required recombinant construct as was confirmed by reamplification with OPA18. The recombinant construct was sequenced using universal sequencing primers SP6 and T7. The sequencing reaction yielded a 601-bp stretch with the purified band from I. mauritiana (A_371; C_211; G_212; T_323) (Figure 2).

3.3. Analysis of Sequence and SCAR Primer Designing. The DNA sequence of the polymorphic band of I. mauritiana was submitted to Genebank (Accession number: EF624353; http://www.ncbi.nlm.nih.gov/). Homology searches were performed within Genebank's non-redundant database using the Basic Local Alignment Search Tool (BLAST) algorithm at http://www.ncbi.nlm.nih.gov/BLAST/ of the National Center for Biotechnology Information (NCBI), with the program BLASTN. BLAST results revealed that the sequence did not have similarity with any known nucleotide sequences. Based on the sequence of the unique polymorphic band, SCAR primers were designed using NCBI primer blast tool (http://www.ncbi.nlm.nih.gov/tools/primer-blast/). Primer designing was done with high stringency, so as to give specific amplification only with I. mauritiana samples (Table 2). 
1

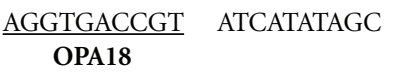

61

\author{
CCCATTCTCC GCTACCCAGC
}

121
TAGGCTGACA CGGCAACTTA IM1F

\begin{abstract}
181 CTGATACCAA CTTGTAACAC
241 CACACCCAGA GTGGTGTCCA

301 AGAAATTACA CTCAACACTT

361 AAGCATCGGA CTGTACATAG

421

$\frac{\text { CCATCCCGGT TTACCAAAAG }}{\text { IM1R }}$

481 AACCTCACTT CTGCTCAAGC

541 GCCACTCTCC CTCGAACCAC
\end{abstract}

AAACAAATTT

CACCAGCTCC

GGCCTATCCT ATCAAACCTA

GGTCGACTCG

AACCTAGGCT

CCCGGACCGG

TCATTCCTTG

GGACCCGCCC

AACTGCCCGC

GAAATATACA

ATGCGGTACA

GTAATGTGGT
CCCTTGCCGT

ATAAATCCCA

AATTGAAACA

CGGGCCCAAA

CAAAAGGGTT

CGGGGCCTGT CGAGGAATCG

\section{ACATCCGGAG TAGTTACCGC CTCCAGGTGC ACAGGCTAAA AAAGAGTTAT ATATCTATTT \\ TATGCCAGAC TCCAAAAGAA}

\section{ATCGCTGAAA CTTCCCTAAG}

GTAGGTGCCC CACACCAAGT ACACTCCTCC ACGGTCACCT

601 A

FIGURE 2: Sequence of 600-bp polymorphic region of I. mauritiana, showing binding sites of RAPD (OPA 18) marker and SCAR Marker (IM1F and IM1R).

3.4. Validation of SCAR Primers. The designed SCAR primer pair (IM1F and IM1R; Table 2) was used to amplify the genomic DNA from I. mauritiana, C. circinalis, A. hondala and $P$. tuberosa. A single, distinct and brightly resolved band of 323 bp was obtained only with the accessions of I. mauritiana, while no amplification product was obtained with $P$. tuberosa, C. circinalis and A. hondala (Figure 3 ). Reduction of the annealing temperatures did not generate any fragment other than the SCAR, confirming the specificity of the SCAR primer for I. mauritiana.

\section{Discussion}

Herbal medicine has been enjoying renaissance among the customers throughout the world. Use of indigenous drugs from plant origin forms a major part of complementary and alternative medicine/traditional medicine (CAM/TM). One of the impediments in the acceptance of herbal formulations is the lack of standardization and quality control profiles. Due to the complex nature and inherent variability of the chemical constituents of plant-based drugs, it is difficult to establish quality control standards. Adulteration of market samples remains a major problem in domestic and export markets due to confusing nomenclature and lack of botanical identification of traded raw drugs [20, 21]. Active chemical composition of the herbal formulation depends on several factors including the use of exact species [22]. According to World Health Organization general guidelines for methodologies on research and evaluation of TMs, first step in assuring quality, safety and efficacy of TMs is correct identification [23].

Panax (ginseng) is a representative genus of medicinal herbs which was subjected to several methods of DNA

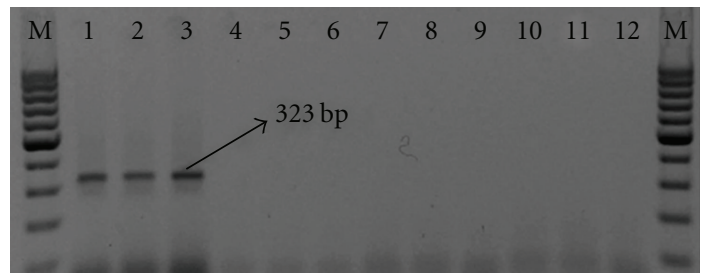

FIGURE 3: Validation of I. mauritiana specific SCAR marker. Lane: M-Standard DNA marker (100-bp DNA ladder); 1-3I. mauritiana; 4-6-A. hondala; 7-9-C. circinalis; 10-12-P. tuberose.

analysis. The methods, applied by several research groups, included PCR-RFLP, AFLP, RAPD, SSR, sequencing of rDNA-ITS region and DNA barcoding. This is an example of how accurate methods for authenticating medicinal plants are necessary to modernize and standardize herbal medicine $[24,25]$.

RAPD is rapid, simple and can be performed even in the absence of prior genetic information of the plant. The fingerprint patterns obtained are consistent irrespective of physical form, age or agroclimatic source [26].

Many technical disadvantages associated with RAPD have, however, raised questions on its fidelity as a genetic marker technique and prevented its widespread use in recent years. The reproducibility of RAPD is affected by DNA quality, primer and template concentration, different thermocyclers and even different sources of DNA polymerase [15]. Therefore, subsequent conversion of RAPD to SCAR markers, by developing longer, hence more specific primers from RAPD sequences, has significantly improved the reproducibility and reliability of PCR assays [27, 28]. 


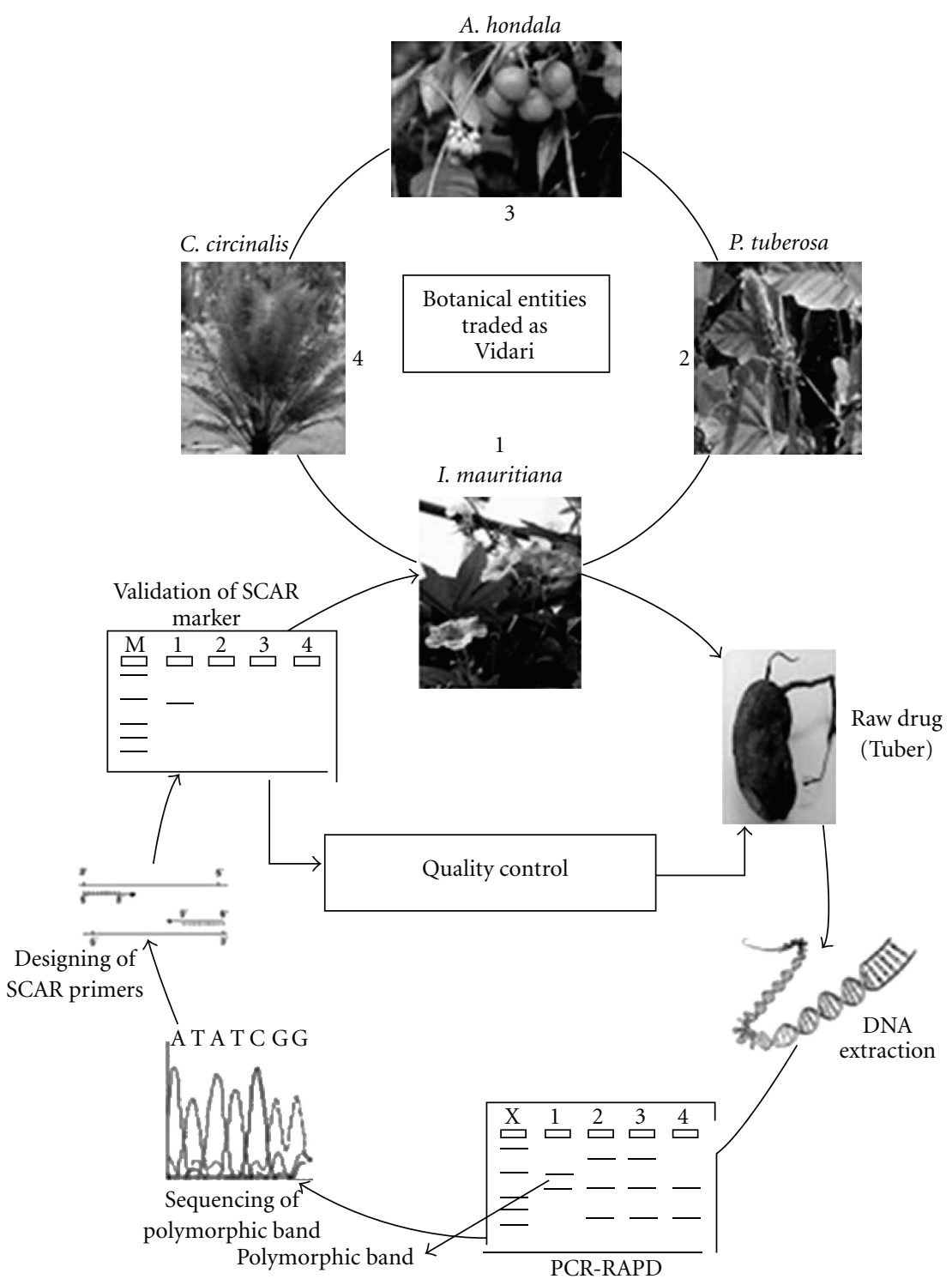

FIGURE 4: Diagrammatic representation of RAPD-SCAR marker development to authenticate I. mauritiana Jacq.

Species-specific SCAR markers have been used in several studies to differentiate important Indian medicinal plants from their close relatives or adulterants $[17,18]$. SCAR marker for discriminating Anthricus sylvestris, an adulterant of Peucedanum praeruptorum and Peucedanum decursivum (syn. Angelica decursiva) used widely in Chinese, Japanese and Korean TM has been reported [28]. Furthermore, development of species-specific DNA markers can increase industrial application of the molecular techniques [27].

In our RAPD analysis, significant genetic polymorphism was observed among I. mauritiana and its adulterants and substitutes. The SCAR primers designed using this sequence variation was found to be specific for I. mauritiana, making the technique more stringent and specific when compared with RAPD marker. The SCAR primers can be used to authenticate the identity of I. mauritiana from other traded "Vidari" candidates like C. circinalis, A. hondala and
P. tuberosa. The complete process involved in developing RAPD-based SCAR marker for authentication of I. mauritiana is summarized in Figure 4. Such efficient, precise and sensitive techniques are required in quality control of raw drugs in the herbal industry.

\section{Funding}

"Centre of Excellence" grant from Ministry of Environment and Forests, Government of India.

\section{Acknowledgments}

Thanks are due to Dr Haridasan, Dr Ravikumar and other field botanists of FRLHT for providing authentic plant specimens and Ms Chandrakala for help with corrections. 
The authors thank Mr D. K. Ved, Director, FRLHT for extending the facility.

\section{References}

[1] Anonymous, The Ayurvedic Pharmacopoeia of India, Part I, Vols II and V, Government of India, Ministry of Health and Family Welfare, Department of Indian Systems of Medicine and Homoeopathy, New Delhi, India, 1999 and 2006.

[2] P. Venkatasubramanian, S. K. Kumar, and S. N. Venugopal, "Use of 'Kshiravidari' as a substitute for 'Vidri' as per Ayurvedic descriptions," Indian Journal of Traditional Knowledge, vol. 8, pp. 310-318, 2009.

[3] R. N. Chopra, S. L. Nayar, and I. C. Chopra, Glossary of Indian Medicinal Plants, Council for Scientific and Industrial Research, Government of India, New Delhi, India, 1992.

[4] G. Pandey, Dravyaguna Vijnana, Part III Reprint, Chowkhamba Krishnadas Academy, Varanasi, India, 2004.

[5] D. K. Ved and G. S. Goraya, Demand and Supply of Medicinal Plants in India, Bishen Singh Mahendra Pal Singh, Dehradun, India, 2008.

[6] P. K. Warrier, V. P. K. Nambiar, and C. Ramankutty, Indian Medicinal Plants: A Compendium of 500 Species, vol. 3, Orient Longman, Chennai, India, 2007.

[7] S. Karthik, C. Chandrakala, and P. Venkatasubramanian, "Phytochemical and Microscopic analysis of tubers of Ipomea mauritiana Jacq. (Convolvulaceae)," Pharmacognosy Magazine, vol. 4, pp. 272-278, 2009.

[8] V. V. Sivarajan and I. Balachandran, Ayurvedic Drugs and Their Plant Sources, Oxford and IBH Publishing, New Delhi, India, 1994.

[9] P. R. Rastogi, B. N. Mehrotra, and M. Srivastava, Compendium of Indian Medicinal Plants, vol. 1, Central Drug Research Institute, Lucknow, India, 1990.

[10] P. R. Rastogi, B. N. Mehrotra, and M. Srivastava, Compendium of Indian Medicinal Plants, vol. 3, Central Drug Research Institute, Lucknow, India, 1991.

[11] Y.-B. Zhang, P.-C. Shaw, C.-W. Sze, Z.-T. Wang, and Y. Tong, "Molecular authentication of Chinese herbal materials," Journal of Food and Drug Analysis, vol. 15, no. 1, pp. 1-9, 2007.

[12] K. Joshi, P. Chavan, D. Warude, and B. Patwardhan, "Molecular markers in herbal drug technology," Current Science, vol. 87, no. 2, pp. 159-165, 2004.

[13] F. Qu, J. Zhou, Z. Zhou, H. Li, and E. Burrows, "Genetic analysis of Aralia cordata Thunb. by RAPD," African Journal of Traditional, Complementary and Alternative Medicines, vol. 6, no. 1, pp. 17-22, 2009.

[14] J. Wang, W. Y. Ha, F. N. Ngan, H.-P. P. But, and P. C. Shaw, "Application of sequence characterized amplified region (SCAR) analysis to authenticate panax species and their adulterants," Planta Medica, vol. 67, pp. 781-783, 2001.

[15] P. Theerakulpisut, N. Kanawapee, D. Maensiri, S. Bunnag, and P. Chantaranothai, "Development of species-specific SCAR markers for identification of three medicinal species of Phyllanthus," Journal of Systematics and Evolution, vol. 46, no. 4, pp. 614-621, 2008.

[16] K. M. Devaiah and P. Venkatasubramanian, "Development of SCAR marker for authentication of Pueraria tuberosa (Roxb. ex. Willd.) DC, Current Science, vol. 94, no. 10, pp. 13061308, 2008.
[17] K. M. Devaiah and P. Venkatasubramanian, "Genetic characterization and authentication of Embelia ribes using RAPDPCR and SCAR marker," Planta Medica, vol. 74, no. 2, pp. 194196, 2008.

[18] B. G. Milligan, “Total DNA isolation,” in Molecular Genetic Analysis of Populations, A. R. Hoelzel, Ed., pp. 29-64, IRL Press, Oxford, UK, 1998.

[19] F. C. Fai and F. N. Ngan, "Quantification of DNA," in Authentication of Chinese Medicinal Materials by DNA Technology, P. C. Shaw, J. Wang, and H.-P. P. But, Eds., World Scientific, Singapore, 2002.

[20] B. Patwardhan, D. Warude, P. Pushpangadan, and N. Bhatt, "Ayurveda and traditional Chinese medicine: a comparative overview," Evidence-Based Complementary and Alternative Medicine, vol. 2, no. 4, pp. 465-473, 2005.

[21] B. Saad, H. Azaizeh, G. Abu-Hijleh, and O. Said, "Safety of traditional Arab herbal medicine," Evidence-Based Complementary and Alternative Medicine, vol. 3, no. 4, pp. 433-439, 2006.

[22] F. Firenzuoli and L. Gori, "Herbal medicine today: clinical and research issues," Evidence-Based Complementary and Alternative Medicine, vol. 4, no. 1, pp. 37-40, 2007.

[23] Anonymous, "WHO general guidelines for methodologies onresearch and evaluation of traditional medicine," February 2010, http://whqlibdoc.who.int/hq/2000/WHO_EDM_TRM_ 2000.1.pdf.

[24] P. Y. Yip, C. F. Chau, C. Y. Mak, and H. S. Kwan, "DNA methods for identification of Chinese medicinal materials," Chinese Medicine, vol. 2, p. 9, 2007.

[25] J. Song, H. Yao, Y. Li et al., "Authentication of the family Polygonaceae in Chinese pharmacopoeia by DNA barcoding technique," Journal of Ethnopharmacology, vol. 124, pp. 434-439, 2009.

[26] V. M. Shinde, K. Dhalwal, K. R. Mahadik, K. S. Joshi, and B. K. Patwardhan, "RAPD analysis for determination of components in herbal medicine," Evidence-Based Complementary and Alternative Medicine, vol. 4, no. 1, pp. 21-23, 2007.

[27] W. Dyaneshwar, C. Preethi, J. Kalpana, and P. Bhushan, "Development and Application of RAPD-SCAR Marker for Identification of Phyllanthus emblica LINN," Biological \& Pharmaceutical Bulletin, vol. 29, pp. 2313-2316, 2006.

[28] B. K. Choo, B. C. Moon, Y. Ji, B. B. Kim, G. Choi, T. Yoon et al., "Development of SCAR markers for the discrimination of three species of medicinal plants, Angelica decursiva (Peucedanum decursivum), Peucedanum praeruptorum and Anthricus sylvestris, Based on the internal transcribed spacer (ITS) sequence and random amplified polymorphic DNA (RAPD)," Biological \& Pharmaceutical Bulletin, vol. 32, pp. 24-30, 2009. 


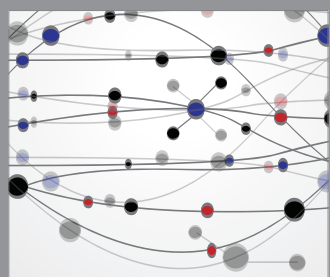

The Scientific World Journal
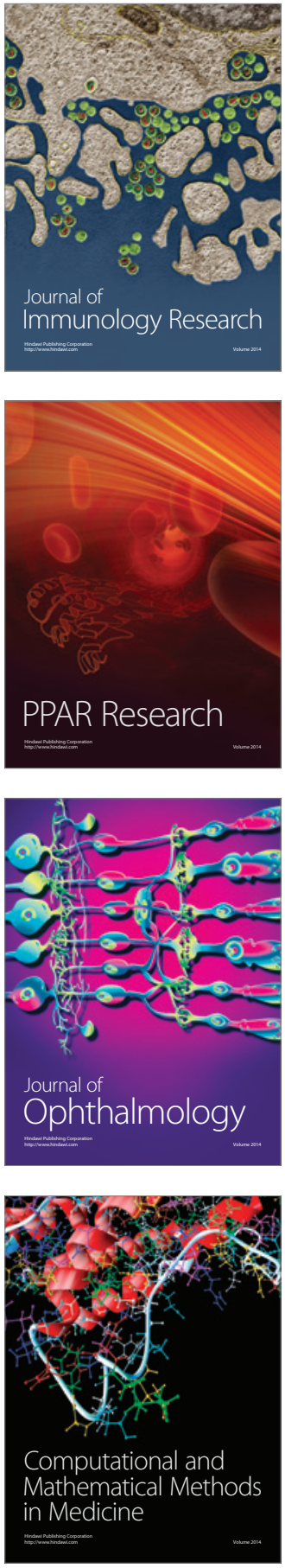

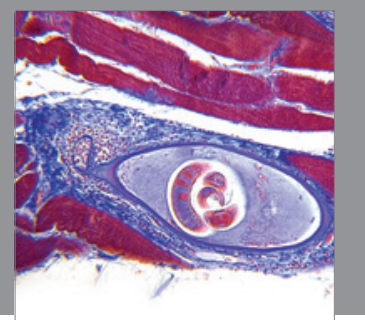

Gastroenterology

Research and Practice
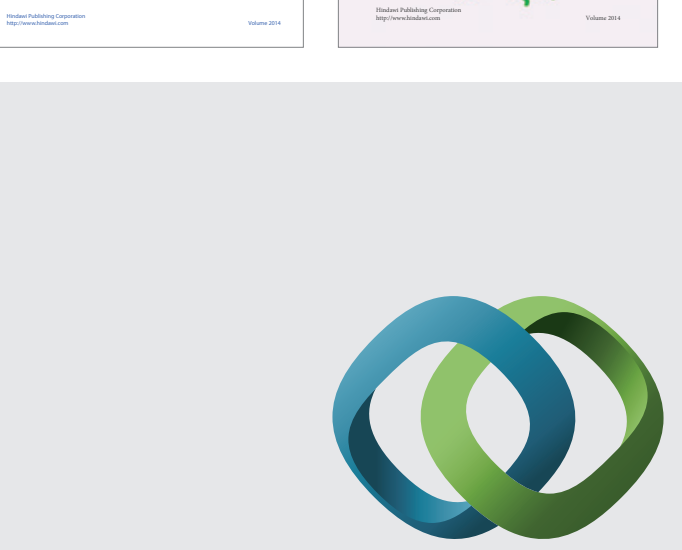

\section{Hindawi}

Submit your manuscripts at

http://www.hindawi.com
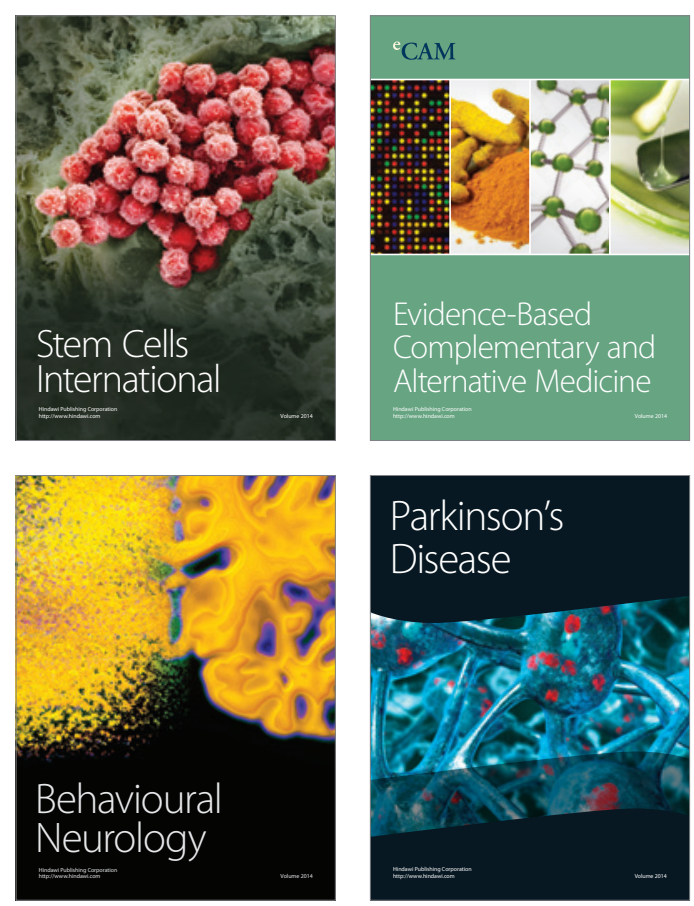

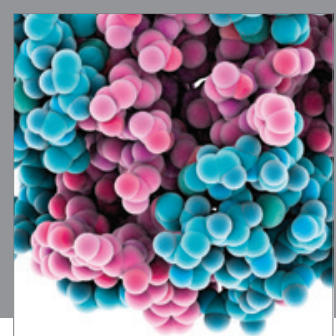

Journal of
Diabetes Research

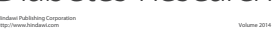

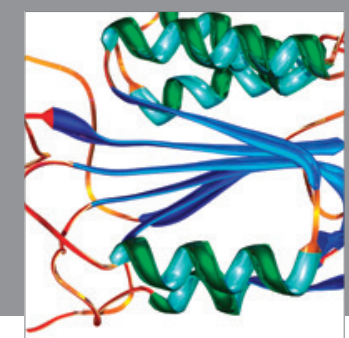

Disease Markers
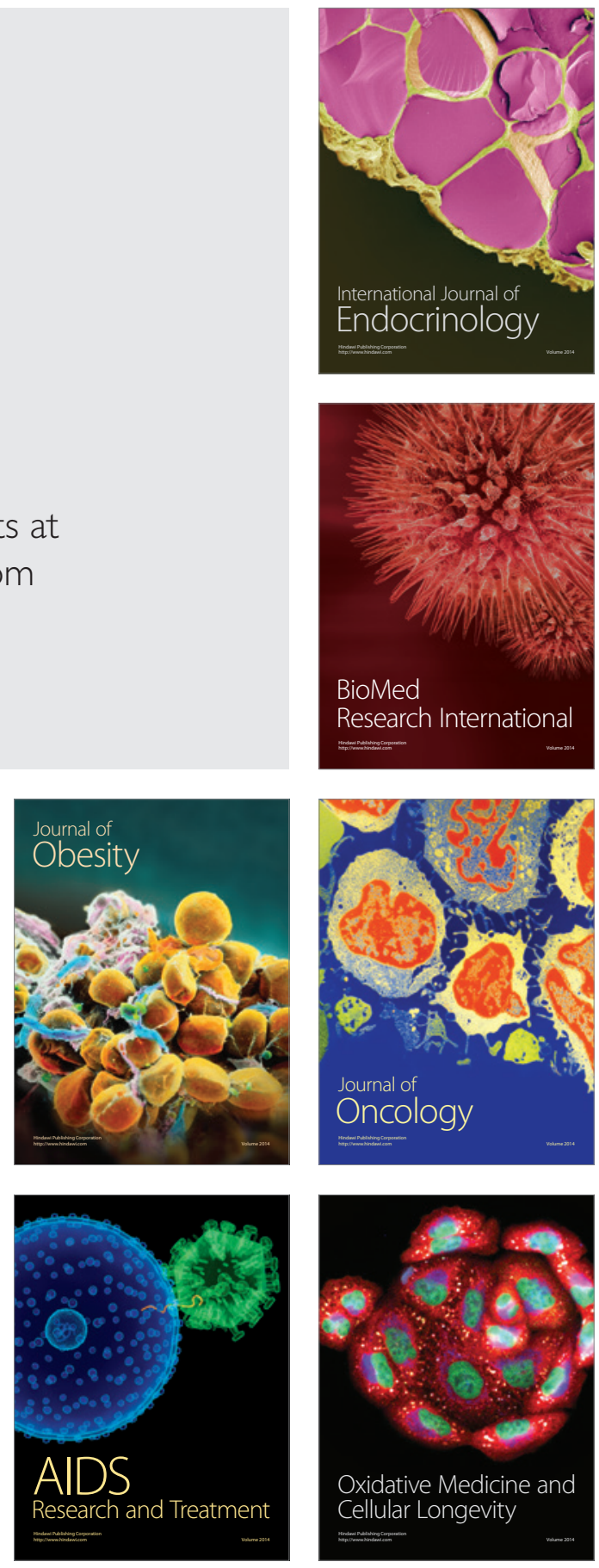